\title{
ASSESSMENT OF DIFFERENTIATION IN NATURAL GREEN SPACES PROVISION IN WARSAW USING ACCESSIBLE NATURAL GREENSPACE STANDARD (ANGSt)
}

\author{
Gabriela Maksymiuk ${ }^{\bowtie}$, Renata Giedych, Agata Winiarska \\ Faculty of Civil and Environmental Engineering, Warsaw University of Life Sciences - SGGW, Warsaw
}

\begin{abstract}
The main aim of the study was to assess the differentiation of natural green spaces (NGS) provision across Warsaw districts. Provision of NGS was measured for two quantitative metrics: availability and accessibility using a methodology adopted from British Accessible Natural Greenspace Standard (ANGSt). Availability was measured as a ratio of natural green spaces per capita. Accessibility was calculated as a derivative of the size of the area and their distance from the residential areas. According to the ANGSt recommendations, each resident should have access to natural green areas of various sizes (from 2 to 500 ha), located in a radius between $300 \mathrm{~m}$ and $10 \mathrm{~km}$ from the place of residence. Our study shows that despite the large share of natural green spaces in the total area of the city $(24.7 \%)$, access to NGS and a target of minimum 2 ha of NGS per 1,000 inhabitants in particular Warsaw districts is limited due to the uneven distribution of NGS within a city structure. In total approximately $60 \%$ of the city's residential areas lack access to NGS over 2 ha at a distance of $300 \mathrm{~m}$.
\end{abstract}

Key words: green infrastructure, quality of life, urban green spaces

\section{INTRODUCTION}

Natural green spaces (NGS) are one of the crucial elements of city's green infrastructure. They provide a range of ecosystem services that are of fundamental importance to human well-being (Bolund \& Hunhammar, 1999; Costanza et al., 2014; Hansen \& Pauleit, 2014; Koc, Osmond \& Peters, 2017; Ferguson, Roberts, McEachn \& Dallimer, 2018). Natural green spaces are especially important in terms of sustaining natural environmental processes, mitigating the urban stress and enabling city dwellers contact with nature. Provision of NGS is an important measure of the quality of the urban environment (Quatrini et al., 2018) and play a key role in assessment of ecological and social functioning of cities (James et al., 2009). Availability of natural green areas within a city limits is often used in different evaluations and rankings of cities, e.g. City Biodiversity Index (Chan et al., 2014), Spatially Adjusted Liveability Index (Economist Intelligence Unit, 2012), European Green Capital (European Commission, 2010). An equally important indicator is accessibility, a measure that refer to the proximity of specific green spaces to places where people live (Gupta, Roy, Luthra, Maithani \& Mahavir, 2016; Biernacka \& Kronenberg, 2018; Silva, Viegas, Panagopoulos \& Bell, 2018).

The issue of accessibility to urban green areas is one of the key aspects of sustainable spatial planning and a major factor influencing a frequent use of NGS, and 
Maksymiuk, G., Giedych, R., Winiarska, A. (2019). Assessment of differentiation in natural green spaces provision in Warsaw using Accessible Natural Greenspace Standard (ANGSt). Acta Sci. Pol. Architectura, 18 (3), 45-53. doi: 10.22630/ASPA.2019.18.3.34

therefore improving the well-being of urban dwellers (Schipperijn, Stigsdotter, Randrup \& Troelsen, 2010; Gupta et al., 2016). Therefore, it is significant that all the housing areas have accessible and approachable urban green spaces at multifarious hierarchical levels for enhancing urban quality of life (Van Herzele \& Wiedemann, 2003).

The main aim of this study was to assess the differentiation of natural green spaces provision across Warsaw districts, with a special emphasis put on their amount and physical availability.

\section{MATERIAL AND METHODS}

Provision of natural green spaces (NGS) in Warsaw was measured for two quantitative metrics: availability related to the total stock of NGS within a city boundaries, and accessibility which refer to a proximity of NGS to residential areas. Detailed methodology of NGS provision was adopted from Accessible Natural Greenspace Standard - ANGSt (Natural England, 2010), a tool developed in the middle of 1990s in Great Britain aimed at enabling city dwellers contact with nature (Harrison, Burges, Millward \& Dawe, 1995; Pauleit, Slinn, Handley \& Lindley, 2003). Nowadays this tool is considered as a measure supporting green infrastructure implementation (Natural England, 2010; Hansen \& Pauleit, 2014; Koc et al., 2017; Ferguson et al., 2018).

Availability was measured as a ratio of natural green spaces per capita. It enables to determine the degree of meeting the recommended provision of at least 2 ha of NGS per 1,000 inhabitants (Harrison et al., 1995). Accessibility was calculated as a derivative of the NGS area and their distance from the residential areas. Accessibility of NGS was examined on the base of following principles set up in ANGSt (Fig. 1):

- NGS of at least 2 ha should be located no more than $300 \mathrm{~m}$ from home;

- NGS of at least 20 ha, should be located no more than $2 \mathrm{~km}$ from home;

- NGS of at least 100 ha, should be located no more than $5 \mathrm{~km}$ from home;

- NGS of at least 500 ha, should be located no more than $10 \mathrm{~km}$ from home.

Data for NGS identification, spatial analysis, as well as metrics calculations were obtained from the study: Potential for green infrastructure development in Warsaw elaborated on commission of Department of Architecture and Spatial Planning of the Capital City of Warsaw in 2017. As natural green spaces according to ANGSt methodology was considered "places where human control and activities are not intensive so that a feeling of naturalness is allowed to predominate" (Natural England, 2010), i.e.: forests and woodlands, extensively used meadows and fallow lands, open water and natural banks of rivers and reservoirs. All analysis were performed for Warsaw districts which differs significantly in terms of total area, population and land use structure (the table). The potential supply of natural green spaces within specific districts results from the land use structure. It should be noticed that in some districts the forests and woodlands predominate in the land use structure (e.g. in Wesoła, where they cover $57.2 \%$ of

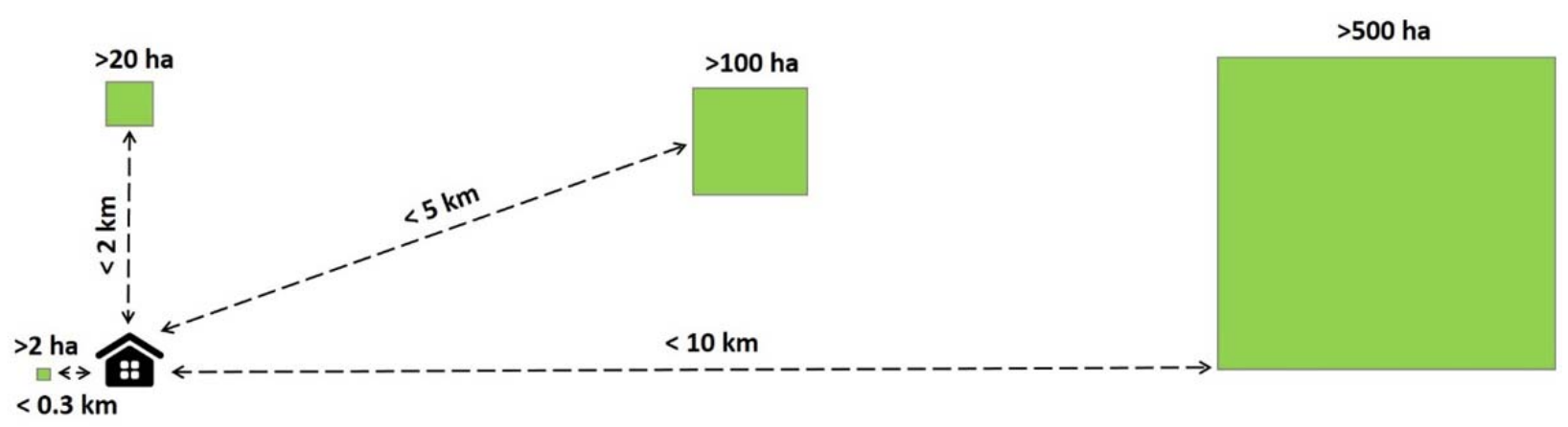

Fig. 1. The principle of accessibility model functioning according to ANGSt (own elaboration) 
Maksymiuk, G., Giedych, R., Winiarska, A. (2019). Assessment of differentiation in natural green spaces provision in Warsaw using Accessible Natural Greenspace Standard (ANGSt). Acta Sci. Pol. Architectura, 18 (3), 45-53. doi: 10.22630/ASPA.2019.18.3.34

a total area). Furthermore, there are districts where the amount of extensively used meadows and midfield green belts within agricultural land is significant (e.g. Białołęka, or Wilanów, where they make 15.2 and $13.8 \%$ of a total districts' area respectively). Besides, in more urbanised and built-up districts (e.g. Praga Północ, Śródmieście or Żoliborz) the potential for provision of natural green spaces relies on the amount of fallow land and water bodies, which are described in the table as "other land uses".

\section{RESULTS}

The study shows that the availability of NGS is varying significantly across Warsaw districts (Fig. 2). In two districts (Ochota and Ursus) NGS is a scarce resource, but at the same time, in majority of Warsaw districts, the level of 2 ha of NGS per 1,000 inhabitants is achieved, and moreover in five districts it is exceeded more than 10 times (Białołęka, Rembertów, Wawer, Wesoła and Wilanów). This great supply of

Table. General info of study area (Warsaw Statistical Office, 2017)

\begin{tabular}{|c|c|c|c|c|c|c|c|c|c|}
\hline \multirow{4}{*}{ Districts } & \multirow{4}{*}{$\begin{array}{l}\text { Area } \\
\text { (ha) }\end{array}$} & \multirow{4}{*}{$\begin{array}{l}\text { Population } \\
\text { grand } \\
\text { total }\end{array}$} & \multicolumn{7}{|c|}{ Land use structure in $\%$ of total area } \\
\hline & & & \multicolumn{2}{|c|}{ agricultural land } & \multirow{3}{*}{$\begin{array}{c}\text { forests } \\
\text { and } \\
\text { woodlands }\end{array}$} & \multicolumn{3}{|c|}{ built-up and urbanised areas } & \multirow{3}{*}{$\begin{array}{l}\text { other } \\
\text { land } \\
\text { uses }\end{array}$} \\
\hline & & & \multirow[b]{2}{*}{ total } & \multirow{2}{*}{$\begin{array}{c}\text { of which } \\
\text { arable } \\
\text { land }\end{array}$} & & \multirow[b]{2}{*}{ total } & \multicolumn{2}{|c|}{ of which } & \\
\hline & & & & & & & $\begin{array}{l}\text { residential } \\
\text { areas }\end{array}$ & $\begin{array}{c}\text { transport } \\
\text { areas }\end{array}$ & \\
\hline Bemowo & 2495 & 122210 & 17.4 & 16.1 & 10.5 & 71.3 & 22.2 & 15.7 & 0.8 \\
\hline Białołęka & 7304 & 119347 & 37.4 & 22.2 & 15.7 & 40.6 & 16.3 & 9.7 & 6.2 \\
\hline Bielany & 3234 & 132026 & 10.0 & 7.9 & 24.4 & 58.5 & 17.9 & 12.7 & 7.1 \\
\hline Mokotów & 3542 & 217577 & 21.0 & 17.5 & 0.7 & 70.8 & 22.6 & 19.1 & 7.5 \\
\hline Ochota & 972 & 83081 & 2.6 & 2.4 & 0.0 & 96.9 & 26.9 & 23.9 & 0.5 \\
\hline Praga Południe & 2238 & 178726 & 5.6 & 5.4 & 2.9 & 83.9 & 27.0 & 30.3 & 7.6 \\
\hline Praga Północ & 1142 & 64904 & 3.3 & 3.3 & 0.0 & 80.1 & 12.5 & 30.9 & 16.5 \\
\hline Rembertów & 1930 & 24148 & 11.3 & 8.7 & 37.9 & 46.5 & 17.1 & 10.6 & 4.2 \\
\hline Śródmieście & 1557 & 117005 & 0.3 & 0.3 & 0.0 & 93.0 & 17.1 & 25.9 & 6.7 \\
\hline Targówek & 2422 & 123941 & 19.9 & 15.1 & 8.0 & 71.4 & 21.9 & 19.2 & 0.7 \\
\hline Ursus & 936 & 59261 & 16.7 & 14.5 & 0.0 & 83.2 & 34.4 & 18.1 & 0.1 \\
\hline Ursynów & 4379 & 150273 & 26.0 & 21.4 & 21.1 & 51.5 & 18.5 & 13.9 & 1.4 \\
\hline Wawer & 7970 & 75991 & 26.0 & 18.2 & 36.6 & 32.5 & 18.7 & 8.1 & 4.9 \\
\hline Wesoła & 2294 & 25106 & 6.5 & 4.7 & 57.2 & 33.8 & 16.6 & 9.4 & 2.4 \\
\hline Wilanów & 3673 & 37511 & 60.0 & 46.2 & 7.4 & 22.8 & 10.2 & 6.6 & 9.7 \\
\hline Włochy & 2863 & 41929 & 23.0 & 21.9 & 2.0 & 74.2 & 14.0 & 32.4 & 0.8 \\
\hline Wola & 1926 & 140111 & 2.5 & 2.4 & 2.6 & 94.8 & 19.0 & 32.9 & 0.1 \\
\hline Żoliborz & 847 & 51441 & 0.0 & 0.0 & 0.0 & 92.4 & 24.8 & 26.1 & 7.6 \\
\hline Warsaw in total & 51724 & 1764588 & 22.3 & 16.7 & 16.9 & 55.9 & 18.6 & 15.8 & 4.8 \\
\hline
\end{tabular}




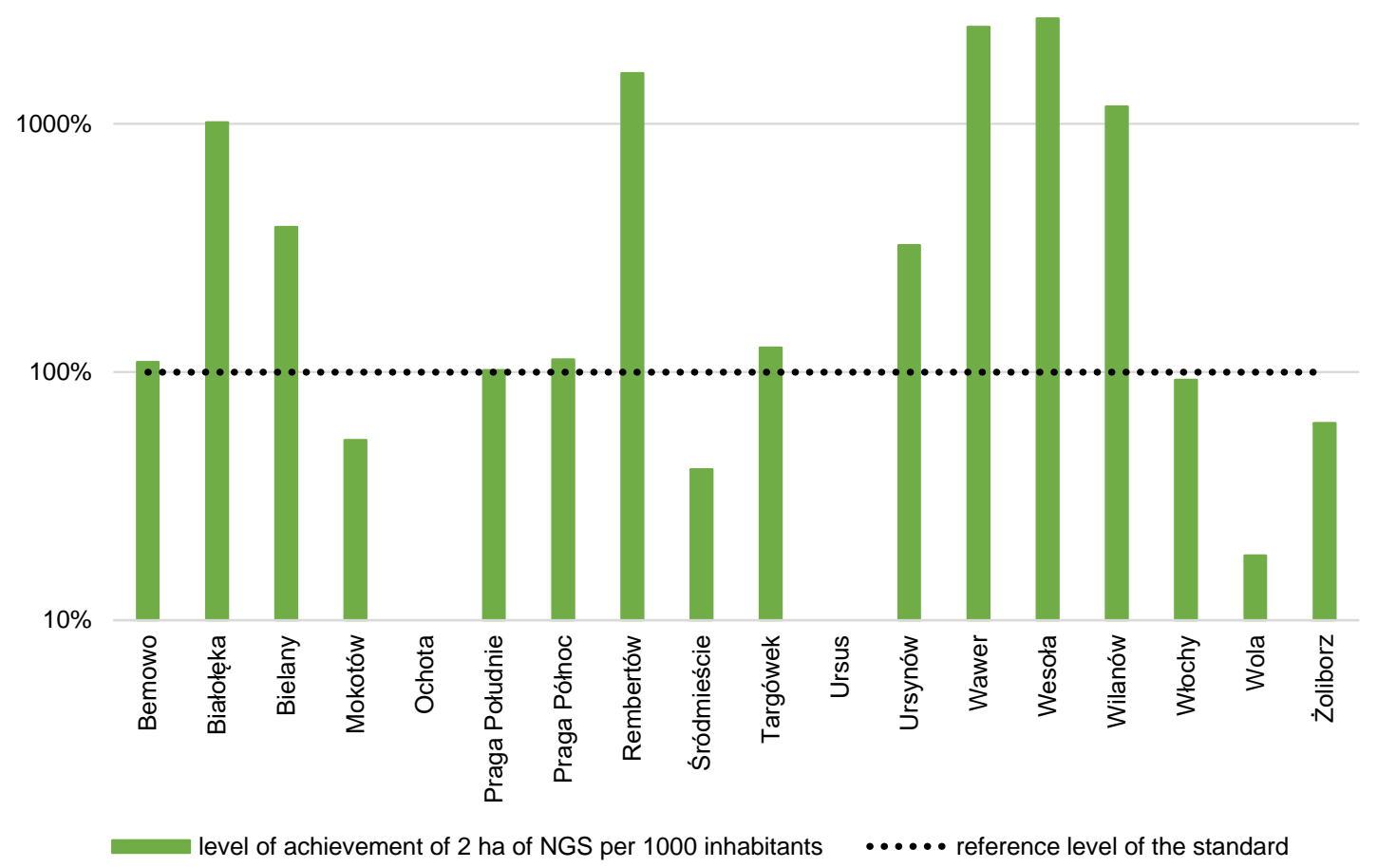

Fig. 2. Availability of NGS in Warsaw districts (own elaboration)

NGS in those districts results from their suburban location characterised by a high amount of woodlands, forests, meadows and also fallow land. At the same time, it is important to notice that in districts that are lacking of natural green spaces at a first glance, due to their intense built-up character (e.g. Praga Północ or Śródmieście), the actual level of achievement of 2 ha per 1,000 dwellers is, in fact, satisfactory. It is mainly owing to presence of open waters or fallow land.

In regards the NGS accessibility, studied on the basis of the NGS area and their distance from the residential areas, the obtained results show that the most difficult to achieve is the possibility of providing a minimum of 2 ha of natural green areas at a distance of a maximum $300 \mathrm{~m}$ from the place of residence (Fig. 3a). The spatial distribution of estates lacking a good access even to small NGS, but located in a walking distance, show that those residential areas concentrate in the downtown and southern-west zone of Warsaw, and mainly on the left side of the Vistula. Districts, where none of the residential estates have access to NGS of minimum 2 ha are Ursus and Włochy (Fig. 4). At the same time, estates located in five other Warsaw districts (Żoliborz,
Targówek, Wola, Śródmieście and Mokotów) have a very limited access those areas (e.g. in Żoliborz only $1 \%$ of residential areas are located in suggested vicinity of NGS according to ANGSt).

The level of meeting the standard of NGS accessibility is growing in regards to next size classes of NGS. Thus, as it concerns the access to NGS of at least 20 ha, located no more than $2 \mathrm{~km}$ from home, it is not ensured in southern west quarter of Warsaw (Fig. 3b). Residential areas located in two districts - Ochota and Ursus, have no access to those NGS at all (Fig. 4), and in Włochy this access is very restricted, as only $12 \%$ of estates possess the access to studied NGS. It can be summarised that the estates located in the next three districts (Bemowo, Wola and Mokotów) are characterised with a moderate access to NGS of at least 20 ha (between 45 and 53\% of neighbourhood with access to studied NGS). Furthermore, residents of as many as seven districts have a maximum access to NGS, as all dwellings are located in the suggested proximity.

The third level of NGS accessibility as recommended in ANGSt, which is at least 100 ha, NGS located no more than $5 \mathrm{~km}$ from home, is achieved 
Maksymiuk, G., Giedych, R., Winiarska, A. (2019). Assessment of differentiation in natural green spaces provision in Warsaw using Accessible Natural Greenspace Standard (ANGSt). Acta Sci. Pol. Architectura, 18 (3), 45-53. doi: 10.22630/ASPA.2019.18.3.34
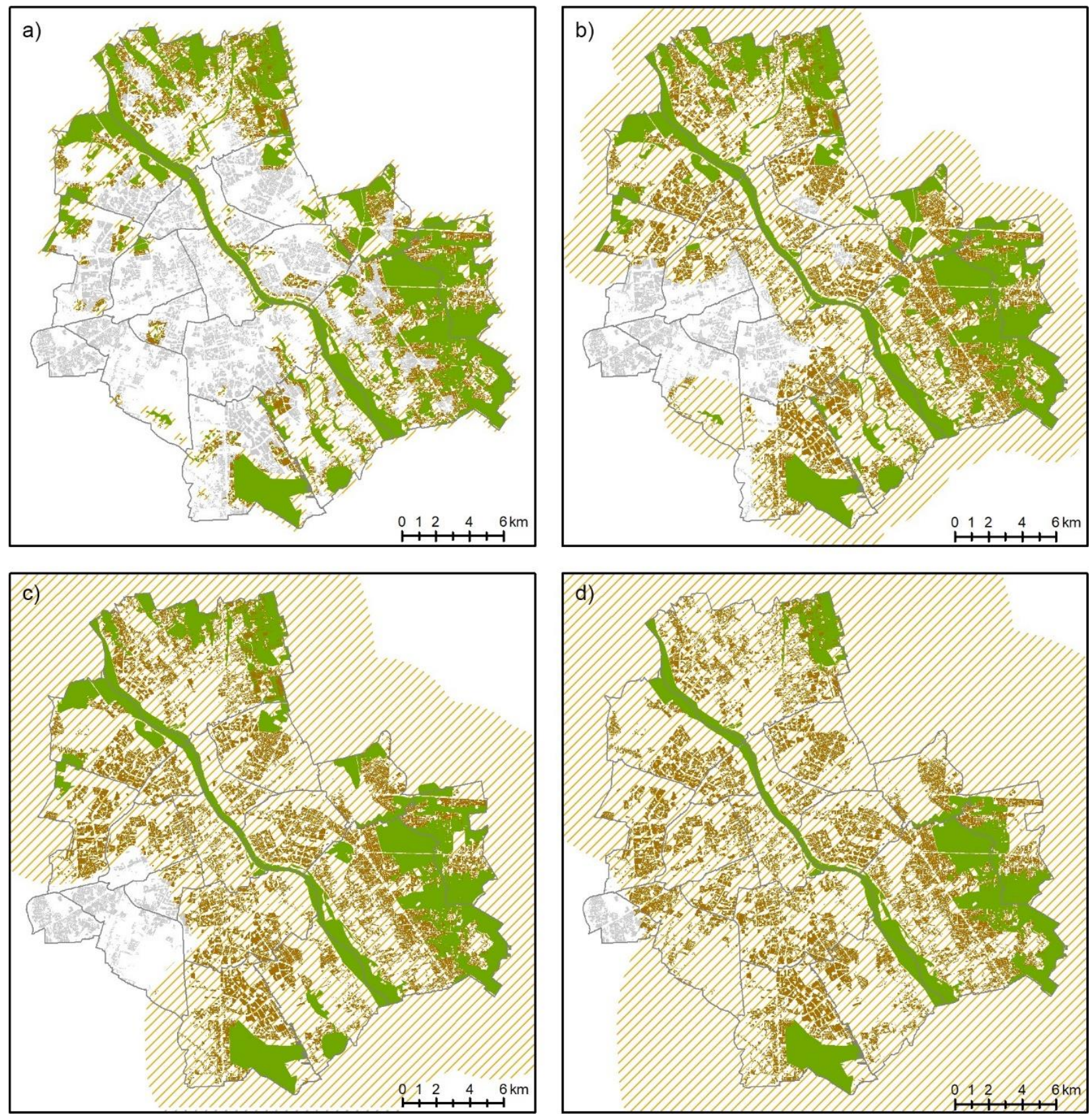

Natural green spaces of an area at least of: a) $>2 \mathrm{ha}$, b) $>20 \mathrm{ha}, \mathrm{c})>100 \mathrm{ha}, \mathrm{d})>500 \mathrm{ha}$

Natural green spaces catchment area of: a) $<0.3 \mathrm{~km}, \mathrm{~b}$ ) $<2 \mathrm{~km}, \mathrm{c}$ ) $<5 \mathrm{~km}, \mathrm{~d}$ ) $<10 \mathrm{~km}$

Residential areas with access to natural green spaces

Residential areas without access to natural green spaces

Fig. 3. Distribution of NGS and their catchment area (own elaboration) 


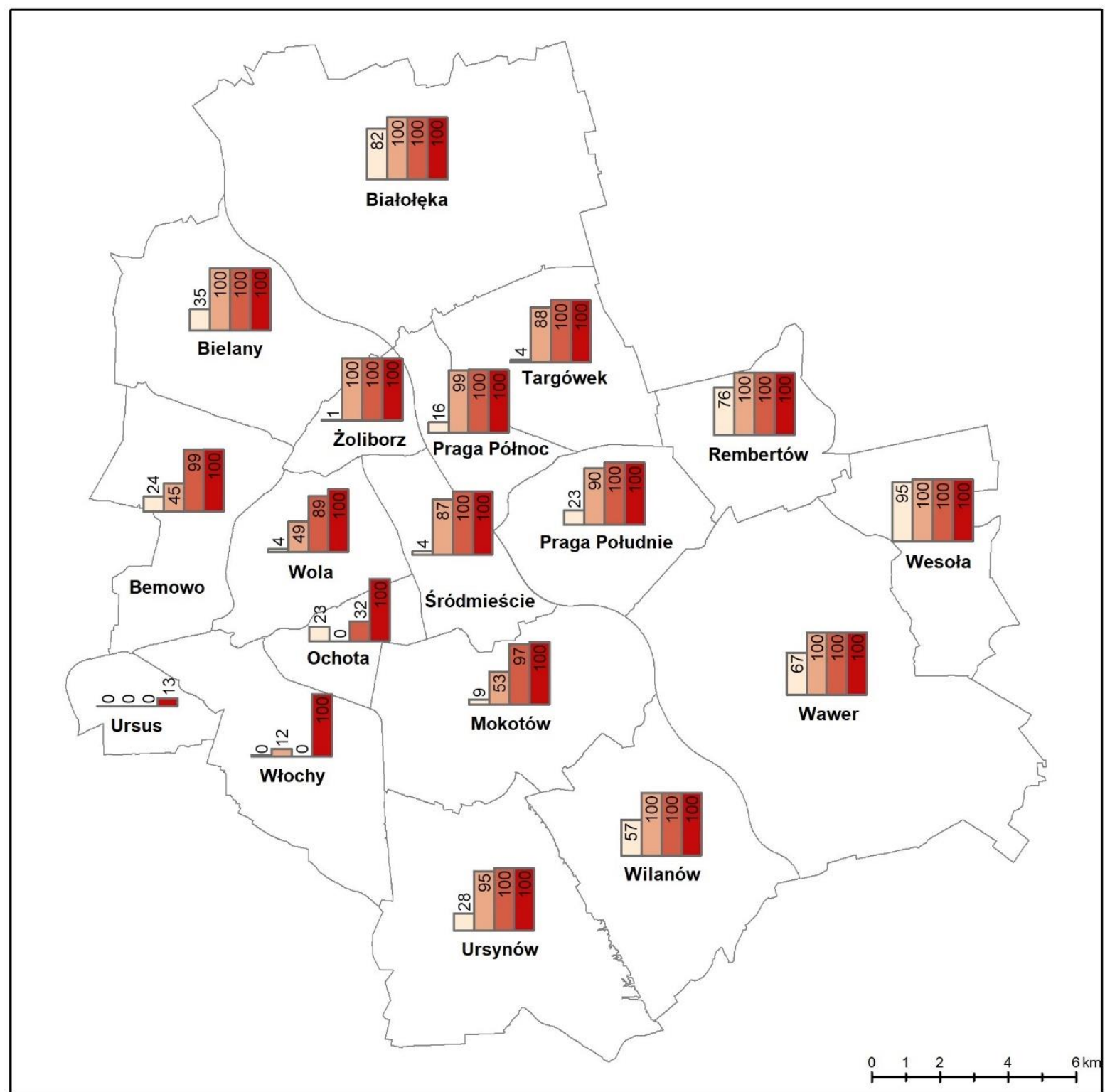

The degree of meeting the standard of accessibility to NGS according to areas size classes (in percents) $>2 \mathrm{ha}$ $>20$ ha $>100$ ha $>500$ ha

Fig. 4. Accessibility of residential areas to NGS in Warsaw districts (own elaboration)

in majority of Warsaw, and only a small part of southern-west quarter of Warsaw is lacking the access (Fig. 3c). In this group, two districts - Ursus and Włochy, have no access to NGS at all, and only $32 \%$ of residential areas in Ochota is located within the assumed distance to 100 ha NGS. At the same time, dwellings located in 12 Warsaw districts have a full access to studied NGS, and next three ones almost reach the maximum level.

By far the easiest to fulfil is a condition of access to the largest NGS that are a minimum of 500 ha located in the $10 \mathrm{~km}$ radius from home (Fig. 3d). In fact, a great majority of Warsaw neighbourhoods are well equipped with such access, and the only district, where 
the estates are lacking this access is Ursus, where only $13 \%$ of estates are well located. The positive results are particularly affected by the Vistula valley, and due to its meridian course and considerable surface it provides access to natural and semi-natural green areas of many districts.

Districts, where the ANGSt can be introduced to the fullest extent, which is at all four suggested levels of accessibility are Wesoła and Białołęka. This is mainly owing to the large share of various open spaces, primarily meadows, forests and woodlands, and their spatial distribution in relations to residential areas.

The research carried out shows that the success of implementing the standard depends to a large extent on the accessibility of the first class of NGS, i.e. areas of minimum 2 ha located in the immediate vicinity of the place of residence. Among the districts with insufficient access of NGS, irrespectively of its area, is Ursus. It should be added that the share of the so-called formal green spaces, such as parks, is also low in this district.

\section{DISCUSSION}

Chen and Chang (2015) believe that the ANGSt concept undoubtedly has many advantages, but it seems to be difficult to apply in highly urbanized areas. Our research confirmed this statement in relation to the NGS of minimum 2 ha located up to $300 \mathrm{~m}$ from the place of residence. However, at the same time our research results show that achieving other levels of accessibility to NGS is feasible. Thus, the distribution structure of NGS should be carefully planned in municipal spatial policy, as some areas are of crucial importance for maintaining accessibility at a proper level.

Furthermore, studies by Zlender and Ward Thompson (2017) affirm that among reasons for not visiting the urban green spaces is a long distance to travel, and thus the distance is perceived as the major barrier to frequent use of peri-urban natural green spaces. In addition, studies by Rojas, Páez, Barbosa and Carrasco (2016) presenting analysis of accessibility to public green spaces based on daily mobility patterns of urban dwellers in two Chilean cities, show that a trip length forms the basis of an adaptive threshold, and variations in accessibility tend to be caused by age and gender, and less by income. These findings suggest an additional dimension that should be considered for further research, as a question appear if the general assumption based on the minimum distances and sizes of the green spaces is enough for a proper planning of accessibility.

The above findings are in line with our research assumption of implementing the ANGSt into the spatial policy, and taking both availability and accessibility to multifarious sizes of NGS into account in future planning, as part of any wider green space strategies. Such approach is also promoted, i.e. by Peilei, Lihua, Wenze and Jiquan (2017), who carried a research for Shanghai and illustrated how the metric called green accessibility index, measuring how well residents are treated in terms of access to different types of public urban green spaces, can actually help improve this access while implemented into the planning process.

\section{CONCLUSIONS}

In our study we have explored the differentiation of provision of NGS across Warsaw districts. The focus of the research has been on availability and accessibility of NGS. Our study shows that despite the large share of natural green spaces in the total area of the city $(24.7 \%)$, access to NGS and a target of minimum 2 ha of NGS per 1,000 inhabitants in particular Warsaw districts is limited due to the uneven distribution of NGS within a city structure. This is particularly evident for downtown districts with the highest population density. In total approximately $60 \%$ of the city's residential areas lack access to NGS over 2 ha at a distance of $300 \mathrm{~m}$. The accessibility targets are fullest fulfilled for NGS over 100 and 500 ha, respectively 90 and $97 \%$ in total. This is related with large forest complexes located in the outskirts of the city and Vistula valley running axially throughout the entire city area. Despite the shortage of access to NGS in downtown areas, contact with nature maybe assured in "formal" urban green areas. Thus the current work can be extended by considering of urban parks, allotment gardens and cemeteries. Further research may reveal to what extent the "formal" urban green spaces may be considered as natural ones, and how they will contribute to improve the provision of NGS in Warsaw. 
Maksymiuk, G., Giedych, R., Winiarska, A. (2019). Assessment of differentiation in natural green spaces provision in Warsaw using Accessible Natural Greenspace Standard (ANGSt). Acta Sci. Pol. Architectura, 18 (3), 45-53. doi: 10.22630/ASPA.2019.18.3.34

\section{REFERENCES}

Biernacka, M. \& Kronenberg, J. (2018). Classification of institutional barriers affecting the availability, accessibility and attractiveness of urban green spaces. Urban Forestry \& Urban Greening, 36, 22-33.

Bolund, P. \& Hunhammar, S. (1999). Ecosystem services in urban areas. Ecological Economics, 29, 293-301.

Chan, L., Hillel, O., Elmqvist, T., Werner, P., Holman, N., Mader, A. \& Calcaterra, E. (2014). User's Manual on the Singapore Index on Cities' Biodiversity. Singapore: National Parks Board, Singapore.

Chen, J. \& Chang, Z. (2015). Rethinking urban green space accessibility: Evaluating and optimizing public transportation system through social network analysis in megacities. Landscape and Urban Planning, 143, 150-159.

Costanza, R., Groot, R., de, Sutton, P., Ploeg, S., van der, Anderson, S. J., Kubiszewski, I., Farber, S. \& Turner, R. K. (2014). Changes in the global value of ecosystem services. Global Environmental Change, 26, 152-158.

Department of Architecture and Spatial Planning of the Capital City of Warsaw (2017). Potential for green infrastructure development in Warsaw. Warsaw.

Economist Intelligence Unit (2012). Best cities ranking and report. Retrieved from: http://na-abk.marketo.com/rs/ eiu2/images/EIU_BestCities.pdf

English Nature (2010). Accessible Natural Greenspace Standard. Retrieved from: http://publications.naturalengland.org.uk/publication/65021/ [access 15.11.2018].

European Commission (2010). Making our cities attractive and sustainable. How the EU contributes to improving the urban environment. Luxembourg.

Ferguson, M., Roberts, H. E., McEachn, R. R. C. \& Dallimer, M. (2018). Contrasting distributions of urban green infrastructure across social and ethno-racial groups. Landscape and Urban Planning, 175, 136-148.

Gupta, K., Roy, A., Luthra, K., Maithani, S. \& Mahavir (2016). GIS based analysis for assessing the accessibility at hierarchical levels of urban green spaces. Urban Forestry \& Urban Greening, 18, 198-211. doi: 10.1016/ j.ufug.2016.06.005

Hansen, R. \& Pauleit, S. (2014). From Multifunctionality to Multiple Ecosystem Services? A Conceptual Framework for Multifunctionality in Green Infrastructure Planning for Urban Areas. AMBIO, 43, 516-529.

Harrison, C., Burges, J., Millward, A. \& Dawe, G. (1995). Accessible natural greenspace in towns and cities. A review of appropriate size and distance criteria (Report 153). English Nature Research, Peterborough.

James, P., Tzoulas, K., Adams, M. D., Barber, A., Box, J., Breuste J., Elmqvist T., Frith, M., Gordon, C., Greening,
K. L., Handley, J., Haworth, S., Kazmierczak, A. E., Johnston, M., Korpela, K., Moretti, M., Niemelä, J., Pauleit, S. \& Ward Thompson, C. (2009). Towards an integrated understanding of green space in the European built environment. Urban Forestry \& Urban Greening, 8 (2), 65-75.

Koc, C. B., Osmond, P. \& Peters, A. (2017). Towards a comprehensive green infrastructure typology: a systematic review of approaches, methods and typologies. Urban Ecosystems, 20, 15-35.

Natural England (2010). 'Nature Nearby’ Accessible Natural Greenspace Guidance. Retrieved from: http://www. ukmaburbanforum.co.uk/docunents/other/nature nearby.pdf [accessed 15.11.2018].

Pauleit, S., Slinn, P., Handley, J. \& Lindley, S. (2003). Promoting the natural green structure of towns and cities: English Nature's Accessible Natural Greenspace Standards model. Built Environment, 14, 157-170.

Peilei, F., Lihua, X., Wenze, Y. \& Jiquan, Ch. (2017). Accessibility of public urban green space in an urban periphery: The case of Shanghai. Landscape and Urban Planning, 165, 177-192. doi: 10.1016/j.landurbplan.20 16.11.007

Quatrini, V., Tomao, A., Corona, P., Ferrari, B., Masini, E. \& Agrimi, M. (2018). Is new always better than old? Accessibility and usability of the urban green areas of the municipality of Rome. Urban Forestry \& Urban Greening, 37, 126-134. doi: 10.1016/j.ufug.2018.07.015

Rojas, C., Páez, A., Barbosa, O. \& Carrasco, J. (2016). Accessibility to urban green spaces in Chilean cities using adaptive thresholds. Journal of Transport Geography, 57, 227-240.

Schipperijn, J., Stigsdotter, U. K., Randrup, T. B. \& Troelsen, J. (2010). Influences on the use of urban green space - A case study in Odense, Denmark. Urban Forestry \& Urban Greening, 9, 25-32. doi: 10.1016/ j.ufug.2009.09.002

Silva, C., Viegas, I., Panagopoulos, T., \& Bell, S. (2018). Environmental Justice in Accessibility to Green Infrastructure in Two European Cities. Land, 7 (4), 1-23. doi: 10.3390/land7040134.

Van Herzele, A. \& Wiedemann, T. (2003). A monitoring tool for the provision of accessible and attractive urban green spaces. Landscape and Urban Planning, 63, 109-126. doi: 10.1016/S0169-2046(02)00192-5

Warsaw Statistical Office (2017). Panorama of Warsaw Districts in 2016. Series Statistical Information and Elaborations. Warszawa.

Zlender, V. \& Ward Thompson, C. (2017). Accessibility and use of peri-urban green space for inner-city dwellers: A comparative study. Landscape and Urban Planning, 165, 193-205. doi: 10.1016/j.landurbplan.2016.06.011 


\section{OCENA ZRÓŻNICOWANIA W DOSTĘPNOŚCI DO NATURALNYCH TERENÓW ZIELENI W WARSZAWIE Z UŻYCIEM STANDARDU DOSTĘPNYCH NATURALNYCH TERENÓW ZIELENI (ANGSt)}

\section{STRESZCZENIE}

Głównym celem badań była ocena dostępności naturalnych terenów zieleni (NTZ) w poszczególnych dzielnicach Warszawy. Dostępność ta była badana pod względem ilościowym dla dwóch wskaźników: udziału NTZ na jednego mieszkańca oraz zasięgu obsługi terenów mieszkaniowych przez NTZ. W badaniach wykorzystano metodykę badania dostępności zastosowaną w brytyjskim standardzie dostępnych naturalnych terenów zieleni (Accessible Natural Greenspace Standard - ANGSt). Zasięg obsługi terenów mieszkaniowych przez NTZ został obliczony jako pochodna ich wielkości i ich odległości od terenów mieszkaniowych. Zgodnie z zasadami określonymi w ANGSt każdy mieszkaniec powinien mieć dostęp do NTZ o różnej wielkości (od 2 ha do $500 \mathrm{ha}$ ), położonych w promieniu między $300 \mathrm{~m}$ a $10 \mathrm{~km}$ od miejsca zamieszkania. Przeprowadzone badania wykazały, że pomimo dużego udziału NTZ w granicach Warszawy (24,7\% ogólnej powierzchni miasta) dostęp do nich oraz wskaźnik 2 ha NTZ na 1000 mieszkańców w poszczególnych dzielnicach Warszawy jest ograniczony ze względu na nierównomierne ich rozmieszczenie w strukturze miasta. W sumie około $60 \%$ terenów mieszkaniowych w mieście nie ma dostępu do NTZ o powierzchni ponad 2 ha, położonych w odległości do $300 \mathrm{~m}$.

Słowa kluczowe: zielona infrastruktura, jakość życia, miejskie tereny zieleni 
